\title{
Corset and Clothing Freedom
}

\author{
Xiaotong Zhu \\ Hangzhou NO.4 High School International Department, Hangzhou, China \\ *Corresponding author. Email: guanghua.ren@gecacademy.cn
}

\begin{abstract}
The main purpose of this article is to study topics about freedom in both modern and ancient society, including feminism and clothing, through historical analysis of corset, therefore analyze the social facts like gender equality and some other issues. The change of the corset also brought about great changes in society, making people realize that some things are not fair. This article will explain some of the causes of the social change, the nature of the change, and show that the change is incomplete, or at least flawed. At the same time, there are significant regional variations existing. What's more, it will also be pointed out here, in the mind of different people, there are completely different ideas.
\end{abstract}

Keywords: Corset, Feminism, Clothing freedom.

\section{INTRODUCTION}

Walking down the streets of most modern cities, there is no doubt that there will be a lot of women of all ages who wear pretty clothes with different styles, loose or slim, just whatever they like. It thanks to the fact that the social position of women nowadays has risen, such as the right to earn their own money, which means it is common for us to see colourful dressing for all women. Long period ago, however, both clothing and work were severely limited for women. This article synthesized the brief history of corset and analyzed the clothing freedom from perspective of feminism.

\subsection{Origin of Corset}

Back in time, the story could be started with Queen Joséphine of France. According to folk history, she wrapped a cloth around her stomach to cover up her pregnancy [1]. Unexpectedly, this brought an extra effect of supporting the breasts, and then led to the fashion trend at that time. The accidental invention, corset, was then born.

\subsection{The Corset is Beautiful, but Harmful}

We can see that in the famous paintings from ancient Europe women in the past had extremely slender waists. Even though the artists may enlarge the effect of women' s body shape, such waist was still incredible. It was corset that built a wonderful stature for women, and made the display of jewelry more prominent at the same time. However, to achieve such beauty, women paid a lot for that. Since the principle of corset is to tighten the waist, the corset consists of some rigid materials like the bone of wale and wooden or metal support frame, which means there must be a certain degree of damage to women's bodies. Among 182 SCI patients referred for PFT in a research, 99 had an injury level of $\mathrm{C} 8$ and above, and 83 an injury level of between T1 and T8 (Eur Respir J 2010). In some situations, material that was hard would squeeze visceral, and even pierce the body straight away. That was extremely outrageous, but women still wear corset for attracting men in order to get higher position in society. Even people knew the dangers of this kind of behavior, but this trend was unable to be avoided. The corset also became a symbol of wealth because this beauty is not that easy to touch. With unaffordable high prices, females are still willing to harm their own bodies in order to follow the fashion and meet the attention from others.

\subsection{Modern Corset}

By the 1910s, corset had fallen down after the rose of some sports against it [2]. Long period of time later, with the help of modern technology and a lot of new materials, corset reappeared with different social meaning and functions. It no longer damages human' $s$ bodies, conversely, it just helps people to improve the effect of fitness. What is more, which is different from the past, not only women, but also men can wear corset. 
Without anything to be surprised about, this phenomenon means that the gender gap is narrowing anyhow, the importance of function is beating gender difference. Although sometimes actresses are required to wear old type corsets for better stage effect on some scenes about ancient palace, they just wear for a while, that is to say corset is gradually disappearing in everyday life. The corsets are modified a lot, which won't bring any damage anymore.

Nevertheless, there is still a question worth exploring in the link between ancient society and modern society. That is the freedom of female. As mentioned in the beginning, women nowadays can wear whatever they like, earn their own money and do almost everything men can do. In the past, however, women could not.

\section{THE RELATION BETWEEN CORSET AND WOMEN'S FREEDOM AND RIGHTS}

\subsection{Female Freedom}

Nevertheless, there is still a question worth exploring in the link between ancient society and modern society. That is the freedom of female. As mentioned in the beginning, women nowadays can wear whatever they like, earn their own money and do almost everything men can do. In the past, however, women could not.

In fact, that was women' s self-cognition that made them realize they were in really poor social status. They then started a feminist movement for equal rights with men, in order to achieve equality between men and women all around the world. Feminism had appeared before mid - century in both American and French journals. British activists tended to call themselves 'Women's Righters' or 'A Woman's Rights Woman'; their issues were named as the 'Woman Question' or 'Woman Problem' or the 'Condition of Woman Question.' Their emphasis was on public organized activity, not on private interpersonal issues or on feelings [3].

After three historical development stages of feminism, which were gender equality in life, gender equality in rights and gender identity, nowadays, women have had basic success. As a result, women gained the right to vote, to receive college education, to work for more reasonable wages, and to file for divorce, which had a significant impact on legislation in the world [4].

However, in some people's subconscious, women are still in a low position without any opportunities to do they want. For example, women' $s$ freedom of dressing has not been fully realized. Although today women have been able to decide what to wear, it does not reach the real free feminism, that is, the freedom of the body and that women are no longer objectified.
There was a puzzling news in 2019, which further showed that women's freedom of dress still needs to be fought for. A Chinese actress, who was famous for Empresses in the Palace [5], She went viral for a series of photos taken at the airport, and the focus was on her clothes. Low-cut, strappy jeans had caused a lot of controversy. Some people said that she has the freedom to do so, which everybody has. While some people accused the actress in public of being immoral, showing their prejudice against women, at the same time because she is a public figure and every small behavior will be magnified. Some extreme people even said it was a publicity stunt, and the actress's body shape wasn't particularly perfect at the time, so she was called out of shape. Because of her previous experience with depression, there were voices saying she should not go out as a depressed person. The most common form of assault was slut-shaming, not only because of what she wore in public, but also because of the way she fought back against the invader in order to defend her rights. Although the actress did nothing wrong with the way she dressed and the way she responded to the abuse, the unequal treatment of the stereotype shows that women's freedom, especially the freedom to dress, is still a work in progress. Women have simply been shackled and restricted for too long in history that they have forgotten their original rights. This actress, to be honest, delivered a message that so many people were asking for, acting as a forerunner, but was then subjected to brutal online abuse. Before that, she even suffered from depression. Research shows that women depression patients are about twice as likely as men, one of the main reasons is the vestige of historical gender bias. In the past, people used to condemn aristocratic women who did not wear a corset, but now they are still abusing female celebrities who dress freely. Is there any actual progress we have made?

\subsection{The Human Mind Has Changed, But Not Completely}

In fact, although the nature of gender problem seems not to be changed, but at least it becomes much less severe. Regarding the symbol object, corset, people in the past never thought about women's willingness, only aim to follow the fashion, pleasing men, care nothing about their own bodies, which straightly led to their certain death [6]. Fortunately, nowadays, following to the change in people's mind, women at least get the right to work. Although there are still some potential rules in gender, such improvement makes it much better than the past. And about clothing, there is at least no longer a certain type of cloth, even bad for health, force women to wear. It is sure that, losing sight of nature, people's mind and relevant policy have all changed, which allow women to live their own lives. Corset, the accidental product of feudal society, seems to have facilitated this process. However, under the influence of 
the general rationality of religion and society, many attempts to make changes were suppressed in the early stage. Women were trying to get reasonable rights, but society didn't accept that. Then, after one effort after another, change happened. From the feminist perspective, this change not only improves women's social status and gives them more freedom, but also protects their bodies, which is undoubtedly a great progress in human history.

Similar to rubber, if women are pushed too hardly, they will spring back even more powerfully. Women learned from the pain of wearing corset that they have to earn their own rights, or they will not find hope. In short, both the rise and decline of corset, which seems to promote the feminist movement, and the change of people's thought across the ages symbolize the progress of the period. It is difficult to completely erase the dirty thoughts in the past, but human beings are always making progress and have become a unique species in the long history. Although people's view of women has changed from so-called subordination to independent individuals, the accumulation of long history still makes people have a great prejudice against women. Of course, women's attitude to their own individual must be based on the feminist point of view, that is, equal to men. But other people do not necessarily recognize, or even criticize their ideas, which is the incomplete point of human ideas change. The complete change should be that the whole society and mankind recognize women's independence and equal rights between men and women, which means the recognition and acceptance of others. It can truly help women to achieve a fair status in society.

\section{DISCUSSION}

\subsection{The factors that led to the emergence of feminism in history}

Such an idea, feminism, which has left a deep imprint on history, cannot be born out of thin air. In fact, in ancient times, compared with men, women had a very low social status and were even deprived of normal rights such as work and entertainment. The patriarchal society at that time believed that women's first duty was to work for the family and please the men. So, they have to wear corset, especially for those aristocratic women, the corset was heavy and tight. Before they realized their terrible situation, thousands of women died annually due to some accidents happened in everyday lives. Therefore, feminism, inspired by the enlightenment thinkers in the 18th century gradually rise, to against the unfair society. For example, the famous female politicians, Mary Wollstonecraft, thought that women had such tags of noble, social elite, spoiled, vulnerable, and at risk of intellectual and moral laziness. She believed that men and women both had responsibility of such a situation, and it is taken for granted that women have much more power than men. Emmeline Pankster was one of the founders of the suffragette movement. She tried to expose sexism in the British social system and founded the Women's Social and Political Union. Their cause was bolstered by a series of brutal defeats that drew attention to the brutality of the legal system. Feminism gradually transformed into an organized social movement in the 19 th century because of a growing belief that women were treated unequally in a male-centered society.

\subsection{The progress of modern feminism compared with the original feminism}

First wave of the feminism movement was around the end of the 19th century, had been a focus of debate for the equality between men and women, and whether women should have civil and political rights, against the privilege of the aristocracy, stressed that men and women in intelligence and ability was no different, one of the most important goal is to fight for political rights. The second movement, generally speaking, began in the 1960s and 1970s and was believed to have originated in the United States. The movement continued into the 1980s. The tone was to eliminate gender differences and demand that all fields be open to the public, especially women [7]. Because of different social environments, women in ancient times were used to being oppressed, and their goals were not radical, so the feminist movement was not really fierce. Feminist as a fashion of textual or discourse criticism did not appear in the West until the political turmoil of the late 1960's. By the end of the 19th century, striving for women's suffrage had become the main purpose of the American women's movement. Many bourgeois women have established women's political participation groups, and actively carry out the campaign for women's suffrage. In 1890, American women established the 'National Suffragette Association', which consolidated the separate suffragette movement into one force and brought the struggle for the right to vote into a new stage. The women's movement swept across the country from west to east, with increasingly diverse and radicalized forms of struggle, such as demonstrations, pickets, purging of political candidates, fasts, and so on. Under strong pressure from the women's movement, some political leaders also publicly supported women's campaigns for suffrage. In 1918, the U.S. House of Representatives approved women's suffrage, which took effect in 1920. Since then, adult women in the United States had the right to vote, along with men. Modern movement which occurred in around the 1960s claimed that women's oppression is the oldest and most profound form of exploitation and the base of all kinds of oppression, and attempt to find a way for women to get rid of oppression. Most of the topics talked about were closely related to women themselves, including gender roles, 
love, marriage, family, childbirth, motherhood, pornography, rape, and women's bodies and psychology. All of them directly touched women's deepest mind and gave out the most naked voice of women [8]. As a result, this led to a more radical, more intense feminist movement.

\subsection{There are differences in the existence and form of feminism in different countries}

However, feminism has not been practiced in all countries and regions. Maybe they tried something like this before but they probably didn't really succeed. According to the 2020 Global Gender Gap Survey [9], Iceland, Norway and Finland have basically reached the point where there is no difference between the sexes which means that men and women have almost the same rights and they can do the same work, entertainment, and anything else. In contrast, the practice of women's rights is not particularly complete in countries such as Iraq and Yemen. The difference in rights between men and women in those countries was very unfair. One of the contributing factors is that they haven't tried to push it or they didn't have a strong desire for gender equality. Conversely, the reason why in some countries women and men are more equal is perhaps they have stronger wishes for gender equality, or maybe they have done political work so well to achieve it. For clothing freedom, it is worth mentioning that in some countries, there is almost no limit to the freedom of dress. People can even walk naked in the street without being criticized. In some other countries, however, in the strictest circumstances, even going downstairs to buy something in pajamas can be booked by the police. In specialized case of women, revealing or peculiar dressing are likely to get strange looks from passers-by, or vulgar jokes from others. A woman's body is her own and she should decide what to wear. Although the idea that women, no matter what shape or color, can wear clothes of their own free seems politically correct, it had attracted a flood of attacks. In China, different women will choose wildly different styles of clothing according to their own tastes, from Hanfu (Traditional Chinese Clothing Style) to Lolita, just because they like it.Whether it's for photo shoots or daily travel, they don't care about anything else. This is the realization of a certain degree of freedom to dress. But this is personal. There will always be people who have a problem with these clothes, and it's not something that can be easily removed.

\section{CONCLUSION}

In a word, although the corset is gorgeous, it is harmful to women's body and not convenient for daily life. Therefore, women have launched a series of movements in order to fight for reasonable rights and protect their bodies, driven by the new era and new ideas.
Then, for women's more reasonable status in society and more basic social gender equality, feminism gradually rose and achieved initial success after a long period of development.

However, there are still many limitations in this paper. For example, all the conclusions are from the previous or recent research results, and there is no updated survey of the current actual situation, lack of coherent investigation on the evolution history of female dress and research on female wearers. Regional differences in gender relations are also not based on new data and need to be updated.

In the future, for more thorough learning, this subject can be developed in the direction of research. Methods such as questionnaire and voting are worth trying to get a conclusion closer to the common people.

\section{REFERENCES}

[1] UKEssays. Feminine Identity and the Corset: A History. 2018.11. .Retrieved from https://www.ukessays.com/essays/culturalstudies/feminine-identity-and-the-corset-culturalstudies-essay.php?vref=1

[2] Deepali B Mudalgi, EVOLUTION OF CORSET, 2018 International Journal of Creative Research Thoughts. Volume 6, Issue 2 April 2018 | ISSN: 2320-2882

[3] Howe, Florence. 'Feminism and the Study of Literature.' The Radical Teacher, no. 3, University of Illinois Press, 1976, pp. 3-11, http://www.jstor.org/stable/20709043

[4] Elisabeth Prugl. The Neoliberalization of Femininsm. New Political Economy 20(4). DOI: 10.1080/13563467.2014.951614, Feminism, 2014

[5] See Rayza's social media sites, https://weibo.com/reyizha?sudaref=cn.bing.com

[6] Frédéric Barbot, Frédéric Lofaso, H Prigent, Isabelle Laffont, Line Falaize, Michèle Lejaille, Nicolas Roche, Relation between corset use and lung function postural variation in spinal cord injury, 2009

[7] Sally Mitchell, Feminism, https://doi.org/10.1002/9781118405376.wbevl119

[8] Manuel Castells. The Power of Identity: The Information Age: Economy, Society and Culture, Volume II (The Information Age) 2nd. Edition.2003. ISBN: 9781405107136

[9] World Economic Forum, Global Gender Gap Report 2020. Retrieved from https://www.weforum.org/reports/gender-gap2020-report-100-years-pay-equality 